\title{
Mycoplasma hominis Infection in Spontaneous Abortions in Thrace Population: Detection by PCR
}

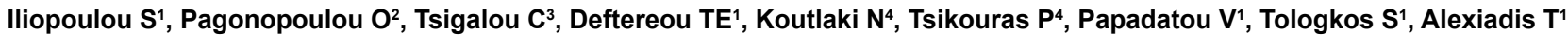
Alexopoulou $\mathbf{S P}^{1}$ and Lambropoulou $\mathbf{M}^{\text {** }}$

${ }^{1}$ Department of Histology-Embryology, Democritus University of Thrace, Alexandroupolis, Greece

${ }^{2}$ Department of Physiology, Democritus University of Thrace, Alexandroupolis, Greec

${ }^{3}$ Department of Medical Biopathology, University General Hospital of Alexandroupolis, Greece

${ }^{4}$ Department of Obstetrics and Gynecology, Democritus University of Thrace, Alexandroupolis, Greece

\begin{abstract}
Objective: The main purpose of this study was the detection of the bacterial strain Mycoplasma hominis, which is one of the 14 Mycoplasma species, in spontaneous abortions.

Methods: Placental tissues from 59 miscarriages of the first and second trimester from different areas of Thrace were used. DNA was extracted using a specific kit and the presence of the Mycoplasma hominis strain was detected by PCR.
\end{abstract}

Results: Among the samples that were examined 2 were proven to be infected by Mycoplasma hominis.

Conclusion: The results of our research imply that a small percentage $(\sim 3.6 \%)$ of spontaneous abortions could be due to the presence of Mycoplasma hominis. PCR is a reliable, sensitive and easy method for the determination of this type of infection and could be applied in the clinical routine.

Keywords: Mycoplasma hominis; PCR; Placenta; Miscarriage

\section{Introduction}

Mycoplasma hominis is a prokaryotic microorganism with stable morphology. It is a member of Mollicutes ("soft skin") group, bacteria which are characterized by the absence of a cell wall. The Mollicutes (about 200 species) are sited in the bacterial group of Gram-positive bacteria.

A remarkable characteristic of Mycoplasmas is the tiny cell size $(0.2$ to 0.3 micrometers) and genome size (0.6 to $1.4 \mathrm{Mb})$. Mycoplasmas can be considered as a minimal self-replicating cell model as their genome has less than 1000 genes [1,2]. In contrast to viruses, Mycoplasmas have both DNA and RNA. Their cytoplasm doesn't have an endoplasmic reticulum or a mesosome. However, they do have ribosomes $70 \mathrm{~S}$ and nuclear substance.

Mycoplasma hominis was first isolated from a human Bartholin's gland abscess in 1937 and was named Pleuro-Pneumonia-LikeOrganisms (PPLO) [3]. Because of the fact that Mycoplasmas don't have a cell wall, they don't compose peptidoglycans. Hence, they are resistant to penicillin and other antibiotics that have an effect on the composition of peptidoglycan [4].

In humans, the genital tract is the main site of colonization for Ureaplasma urealyticum, Mycoplasma hominis, Mycoplasma genitalium, Mycoplasma penetrans, Mycoplasma primatum, and Mycoplasma spermatophilum $[1,5]$

Pathogenetic conditions of the pregnancy like preterm labor, miscarriage etc are generally defined as adverse pregnancy outcomes. Mycoplasma hominis has been positively associated with preterm labor, chorioamnionitis and premature rupture of membranes [6,7].

Mycoplasma can be transmitted through direct contact between hosts, downward from mother to child (either during labor or through the placental membranes) and through transplanted tissues, as well as it can infect the amniotic sac early in gestation $[8,9]$.
It is known that Mycoplasma hominis is associated with harmful effects on women's reproductive health, as recurrent spontaneous abortion [10] and with pregnancy complications, as ectopic pregnancy, preterm birth, preterm prelabour rupture of the membranes (PPROM), low birthweight and late miscarriage $[10,11]$, whereas the positive correlation of M. hominis and infertility is still unclear. In addition, neonatal complications can be caused by maternal infection as lung diseases, meningitis and septicaemia [12].

Many researchers have found evidence indicating that M. hominis infection of the mother can cause reduced gestational age resulting in preterm birth and can also decrease neonatal length and weight. This supports the hypothesis that this specific microorganism has an adverse effect in many aspects of the pregnancy $[13,14]$.

Bacterial vaginosis was also positively associated with early pregnancy loss. However due to the great number of bacteria present in this condition, researchers were unable to identify each specific pathogenetic mechanism involved. M. hominis is considered to be among the infections that carry the highest risk of causing recurrent spontaneous abortions [10]. In the present study, we studied the presence of Mycoplasma hominis infection in placental tissues coming from spontaneous abortions by PCR.

*Corresponding author: Maria Lambropoulou, Associate Professor in Department of Histology-Embryology, Democritus University of Thrace, Dragana, 68100 Alexandroupolis, Greece, Tel: +30 25510 30558; Email; mlambro@med.duth.grt

Received September 29, 2017; Accepted October 08, 2017; Published October 17, 2017

Citation: lliopoulou S, Pagonopoulou O, Tsigalou C, Deftereou TE, Koutlaki N, et al. (2017) Mycoplasma hominis Infection in Spontaneous Abortions in Thrace Population: Detection by PCR. Human Genet Embryol 7: 142. doi:10.4172/21610436.1000142

Copyright: (c) 2017 Iliopoulou S, et al. This is an open-access article distributed under the terms of the Creative Commons Attribution License, which permits unrestricted use, distribution, and reproduction in any medium, provided the original author and source are credited. 


\section{Materials and Methods}

\section{Embryonic samples}

Tissues from 59 miscarriages during the late first and the second trimester of the pregnancy were studied in the laboratory of HistologyEmbryology School of Medicine, Democritus University of Thrace in Alexandroupolis. Tissues were fixed immediately in $10 \%$ buffered formalin.

\section{Sample preparation}

Tissues were placed in special biocassettes, were dehydrated in histokinette and then were embedded in paraffin.

\section{Sample deparaffinization}

Deparaffinization of the tissues was performed using the NuCleoSPIN ${ }^{\oplus}$ Tissue, CAT.No 74095210 kits (MACHEREY-NAGEL, Düren, North Rhine-Westphalia, Germany) according to the manufacturer's instructions. From every tissue, 3-4 paraffin microtome sections of $20 \mu \mathrm{m}$ were taken and were placed in $1.5 \mathrm{ml}$ eppendorf tubes which were then placed in a bath for $10 \mathrm{~min}$ at $56^{\circ} \mathrm{C}$. Excess paraffin was removed from the bottom of the tubes, $1 \mathrm{ml}$ of xylene was added in every tube and samples were shaken to detach the tissue from the tube walls. Tubes were left for $30 \mathrm{~min}$ in room temperature were centrifuged for $3 \mathrm{~min}$ at $11000 \mathrm{~g}$ and the pellet was collected. The procedure was repeated. $1 \mathrm{ml}$ of ethanol was added in each tube, shaken and left for $30 \mathrm{~min}$ in room temperature. After centrifugation for $3 \mathrm{~min}$ at 11000 $\mathrm{g}$ the pellet was collected. The procedure from the step with ethanol was repeated. Ethanol was left to evaporate, then $180 \mu \mathrm{l}$ of lysis buffer and $25 \mu \mathrm{l}$ of proteinase $\mathrm{K}$ were added and mixed. Finally, samples were incubated overnight at $56^{\circ} \mathrm{C}$.

\section{DNA isolation}

Total DNA was isolated by using the, NuCleoSpin ${ }^{\circledR}$ Tissue, Cat. No 74095210 kit (MACHEREY-NAGEL, Düren, NorTh RHINEWESTPHALIA, GERMANY) according to the manufacturer's instructions.

Recently molecular methods like PCR were used to detect Mycoplasmas in several tissues $[15,16]$. In our case, PCR was performed to amplify the DNA sequence of the bacterium (Figure 1: Genbank accession AJ002269). We used the M. hominis, 16S rRNA, rrnB operon primer set plus positive control, 311 bp kit Cat.No SP-10501 (Maxim Bioitech Inc, Rockville, Maryland, USA). The primers included were:

\section{5'oligo: CCGCATGGTTCCGTTGTGAA}

\section{3’oligo: CAAGGTACCGTCAGTCTGCAATCA}

PCR products were separated by $2 \% \mathrm{w} / \mathrm{v}$ agarose gel electrophoresis at $100 \mathrm{~V}$ for 1 hour and stained with ethidium bromide. In each electrophoresis except from the samples, a positive and a negative control was included (Figure 2). After electrophoresis the gel was illuminated with an ultraviolet lamp to view the DNA bands and pictures were taken by a digital camera.

\section{Results}

The results from PCR assays for the detection of Mycoplasma hominis are shown in Figure 2. A band of $311 \mathrm{bp}$ in size indicates the presence of the target sequence. Among the 59 placental samples 33 were from the first trimester and the rest were from the second trimester of the pregnancy. Among each of these groups one specimens was found positive for $M$. hominis infection. So, from the 59 samples tested, two (3.6\%) were found positive for Mycoplasma hominis and the other 57 were negative.

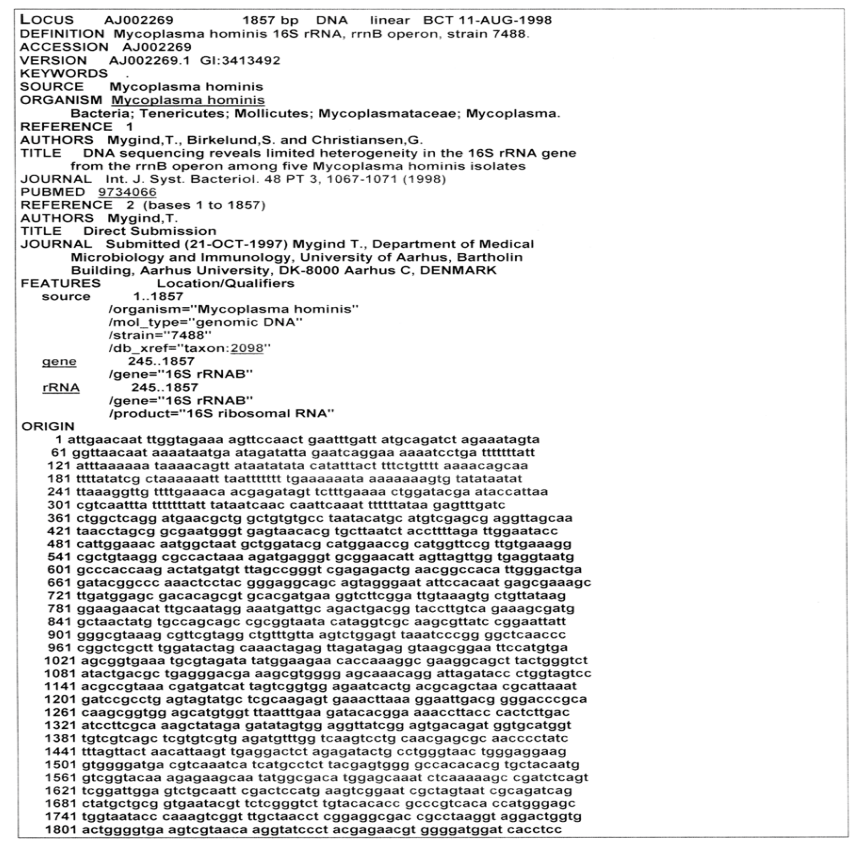

Figure 1: The 16S rRNA gene sequence from the rrnB operon strain 7488 (Genbank accession AJ002269).

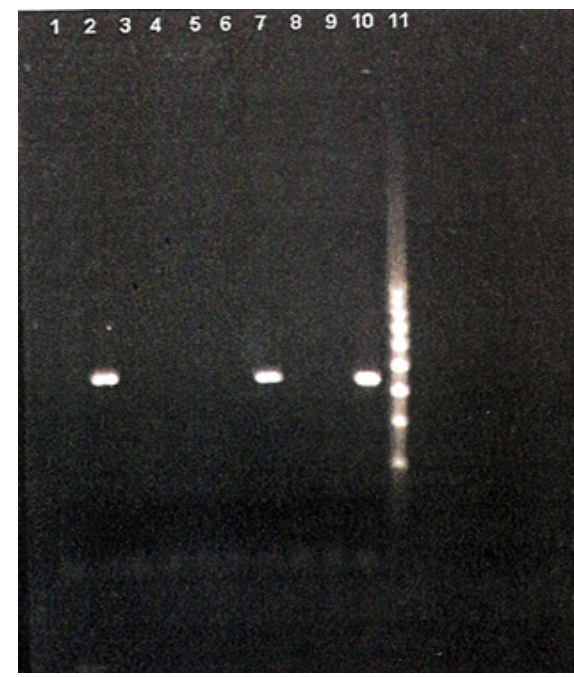

Figure 2: Digital photo of the gel which shows the results from a PCR assay for the detection of Mycoplasma hominis in samples from placenta. Line 1: Negative control, Line 2: PCR positive control, Line 3-6, 8-9: Samples without infection of Mycoplasma hominis, no band is visible, Line 7, 10: A band of 311 bp that indicates the presence of Mycoplasma hominis in that sample, Line 11: MW marker.

No PCR product could be detected in the negative control samples using water instead of the DNA template.

In Figure 2, samples 3-6, 8, 9 resulted in no amplified product and thus we concluded that no Mycoplasma hominis infection was present. A DNA product of $311 \mathrm{bp}$ was amplified in the positive control sample containing the DNA sequence from Mycoplasma hominis, which was included in the kit (sample 2). The same size product was also found in samples 7 and 10, indicating the presence of Mycoplasma hominis infection. All other samples were found negative and thus they are not presented in figures. 


\section{Discussion}

Every five pregnancies one miscarriage occurs. The possible involvement of gestation infection has been well studied. Infections in pregnancy seem to be responsible for up to $15 \%$ of early miscarriages and about $66 \%$ of late miscarriages [17]. Many different viruses have been studied over the years to prove their possible involvement in spontaneous abortions. A well-studied example is the CMV virus. Grammatikopoulou and colleagues have shown that the CMV virus may have a role in abortions even though the incidence percentage is low (1.4\%) [18].

In this study, the presence of Mycoplasma hominis infection was evaluated in placental tissues, using PCR. We used placental tissues since Mycoplasma hominis can be transferred from mother to fetus through the blood stream. DNA of Mycoplasma hominis, specially the DNA sequence of $16 \mathrm{~S}$ rRNA, rrnB operon, was detected by using a specific kit and the molecular method of PCR. In total, fifty-nine DNA samples were collected which came from placentae of 59 cases of spontaneous abortions during the first and second trimester. Among the 59 samples tested, 2 were found positive ( 1 coming from the late $1^{\text {st }}$ trimester group and one from the $2^{\text {nd }}$ trimester group) for Mycoplasma hominis and the other 57 were negative. This result implies that a percentage $\sim 3.6 \%$ of spontaneous abortions could be due to the presence of Mycoplasma hominis.

The detection of Mycoplasma hominis and other ureaplasmas by molecular-based methods, as polymerase chain reaction (PCR), is essential for the diagnosis in second-trimester amniotic fluids and can indicate that infected women are at an increased risk for pregnancy complications [4].

As it was stated, Mycoplasma hominis is a sexually transmitted microorganism that is related to a big number of pathological conditions of pregnant women. In many cases Mycoplasma hominis has been related to chorioamnionitis, fusinitis and postpartum fever but the significance of this relation is not clear [19].

During the transaction of another study, samples were collected from amniotic fluids by amniocentesis during the $16^{\text {th }}$ to $20^{\text {th }}$ week of gestation. Two (2) out of fifty-nine (59) samples were found positive to Mycoplasma hominis. These results indicate that Mycoplasma hominis can infect the amniotic sac early in gestation [5]. These results are in agreement with our study, as in both cases the number of samples and the percentage of infection are the same although we used samples from placenta instead of amniotic fluids. In our study, the molecular method of PCR was used which was proven to be fast, easy, sensitive and reliable for the Mycoplasma hominis detection. These results suggest that Mycoplasma hominis could be transferred from mother to fetus during the gestation and therefore be responsible for preterm labors or miscarriages.

In some cases, bacterial vaginosis and Mycoplasmas may play a causative role in spontaneous abortion and early pregnancy loss [20].

Many studies correlate the existence of large numbers of $M$. hominis with bacterial vaginosis (BV) based on the fact that the microorganism is found more common in women with this specific condition compared to healthy ones. In light of this discovery, there seems to be a need to further examine the mechanisms causing preterm labor and miscarriage in women with $\mathrm{BV}$, so a conclusion can be reached regarding whether or not $M$. hominis works in conjunction with other bacteria present in this condition, or if it has an abortional role of its own $[4,21]$.
Another study of 577 pregnancies has determined the influence of Mycoplasma on peri-post-natal illness arising during the last month of gestation and during the immediate post-partum period. The incidence of contamination was $2.3 \%$ for Mycoplasma hominis [22]. This percentage is very close to the results of our clinical research (3.6\% of the samples from placenta were infected with Mycoplasma hominis) [22].

Intraamniotic infections are achieved in an ascendant way and present the most common and dangerous kind of prenatal infection for the pregnant woman as well as her fetus $[19,23]$. After a spontaneous abortion caused by premature rupture of the fetal membranes (in infected by Mycoplasma hominis women), the fetus is usually of normal size and without malformations. Mycoplasma hominis could be isolated from the placenta and lungs of the fetus during autopsy. This is due to the fact that $M$. hominis mainly causes pneumonia in infants $[8,24]$.

Overall, as stated by Leli et al. [25] the study of Mycoplasma hominis and its association with many pathogenetic conditions of the pregnancy is controversial on all aspects and the international literature seems clearly divided on this issue. Many researchers have published results that indicate no positive correlation between $M$. hominis infection and adverse pregnancy outcome $[26,27]$, while others seem to state just the opposite [12,27]. This could be due to different populations included in the respective studies, different study designs, or different methods for detection. On many occasions there have been reports stating different colonization patterns for M. hominis depending on the socio-economic status and race of the population studied as well as age and sexual activity of the patients $[4,6,8]$.

\section{Conclusion}

In conclusion, in our study Mycoplasma hominis infection was detected in $3.6 \%$ of the placentas from miscarriages in Thrace population, a percentage similar to other studies. Mycoplasma hominis is responsible for a wide spectrum of serious pathological conditions in pregnancy since it has been associated with miscarriages and spontaneous abortions. The use of placental tissue for the detection is convenient, since it is easily accessible in all miscarriages and has been proven to be reliable as it comprises a communicational bridge between mother and fetus. PCR is a fast, easy, sensitive and reliable method for the Mycoplasma hominis detection and should be introduced in laboratory routine.

\section{Acknowledgements}

This study was supported by the Laboratory of Histology-Embryology, Laboratory of Physiology, Laboratory of Medical Biopathology, University General Hospital of Alexandroupolis and Department of Obstetrics \& Gynecology, Medical Department, Democritus University of Thrace, Alexandroupolis, Greece.

\section{References}

1. Waites KB, Taylor-Robinson D (2011) Mycoplasma and ureaplasma. Manual of Clinical Microbiology. $10^{\text {th }}$. ASM Press. Washington, DC, USA

2. Citti C, Blanchard A (2013) Mycoplasmas and their host: Emerging and reemerging minimal pathogens. Curr Trends Microbiol 21: 196-203.

3. Dienes L, Edsall G (1937) Observations on the L-organism of Klieneberger Proc Soc Exp Biol Med 36: 740-744.

4. Taylor-Robinson D, Lamont RF (2010) Mycoplasmas in pregnancy. BJOG 118 164-174.

5. Farhadifar F, Khodabandehloo M, Ramazanzadeh R, Rouhi S, Ahmadi A, et al. (2016) Survey on association between Mycoplasma hominis endocervical infection and spontaneous abortion using Polymerase Chain Reaction. Int $J$ Reprod Biomed 14: 181-186.

6. Latino MA, Botta G, Badino C, Maria D, Petrozziello A, et al. (2017) Association 
Citation: Iliopoulou S, Pagonopoulou O, Tsigalou C, Deftereou TE, Koutlaki N, et al. (2017) Mycoplasma hominis Infection in Spontaneous Abortions in Thrace Population: Detection by PCR. Human Genet Embryol 7: 142. doi:10.4172/2161-0436.1000142

Page 4 of 4

between genital mycoplasmas, acute chorioamnionitis and fetal pneumonia in spontaneous abortions. J Perinat Med.

7. Sobouti B, Fallah S, Mobayen M, Noorbakhsh S, Ghavami Y (2014) Colonization of Mycoplasma hominis and Ureaplasma urealyticum in pregnant women and their transmission to offspring. Iran J Microbiol 6: 219-224.

8. Sampath R, Patel R, Cunningham SA, Arif S, Daly RS, et al. (2017) Cardiothoracic transplant recipient Mycoplasma hominis: An uncommon infection with probable donor transmission. E Bio Medicine 19: 84-90

9. Nigro G, Mazzocco M, Mattia E, Di Renzo GC, Carta G, et al. (2011) Role of the infections in recurrent spontaneous abortion. J Matern Fetal Neonatal Med 24: 983-989.

10. Hosny AE, El-Khayat W, Kashef MT, Fakhry MN (2017) Association between preterm labor and genitourinary tract infections by Trichomonas vaginalis, Mycoplasma hominis, Gram-negative bacillis, and coryneforms. J Chin Med Assoc 80: 575-581.

11. Vouga M, Greub G, Prod'hom G, Durussel C, Roth-Kleiner M, et al. (2014) Treatment of genital mycoplasma in colonized pregnant women in late pregnancy is associated with a lower rate of premature labour and neonatal complications. Clin Microbiol Infect 20: 1074-1079.

12. Donders GG, Van Calsteren K, Bellen G, Reybrouck R, Van den Bosch T, et al. (2009) Predictive value for preterm birth of abnormal vaginal flora, bacteria vaginosis and aerobic vaginitis during the first trimester of pregnancy. BJOG 116:1315-1324.

13. Otgonjargala B, Becker K, Batbaatar G, Tsogtsaikhan S, Enkhtsetseg J, et al. (2017) Effect of Mycoplasma hominis and cytomegalovirus infection on pregnancy outcome: A prospective study of 200 Mongolian women and their newborns. PLoS One 12: e0173283

14. Ataee RA, Golmohammadi R, Alishiri GH, Mirnejad R, Najafi A, et al. (2015) Simultaneous detection of Mycoplasma pneumoniae, Mycoplasma hominis and Mycoplasma arthritidis in synovial fluid of patients with rheumatoid arthritis by multiplex PCR. Arch Iran Med 18: 345-350.

15. Golmohammadi R, Ataee RA, Alishiri GH, Mirnejad R, Mehrabi Tavana A et al. (2014) Design of PCR-based method for detection of a gene-encoding Mycoplasma arthritidis mitogen superantigen in synovial fluid of rheumatoid arthritis patients. Iran J Microbiol 6: 415-20.

16. Giakoumelou S, Wheelhouse N, Cuschieri K, Entrican G, Howie S, et al. (2016)
The role of infection in miscarriage. Hum Reprod Update 22: 116-133.

17. Grammatikopoulou I, Lambropoulou M, Chatzaki E, Deftereou TE, Lambropoulou V, et al. (2012) Molecular diagnosis of CMV infection in fetal aborted tissues in the region of thrace. Clin Exp Obs Gynecol 39: 96-102.

18. Allen-Daniels MJ, Serrano MG, Pflugner LP, Fettweis JM, Prestosa MA, et al (2015) Identification of a gene in Mycoplasma hominis associated with preterm birth and microbial burden in intraamniotic infection. Am J Obstet Gynecol 212: $779-779$.

19. Larsen B, Hwang J (2010) Mycoplasma, Ureaplasma, and adverse pregnancy outcomes: A fresh look. Infect Dis Obstet Gynecol 2010.

20. Taylor-Robinson D (2007) The role of mycoplasmas in pregnancy outcome. Best Pract Res Clin Obstet Gynaecol. 21: 425-438.

21. Jacqui P, Sedallian A (1992) Role of mycoplasmas in the last months of pregnancy and postpartum pathology. Prospective study of 577 pregnancies. Rev Fr Gynecol Obstet 87:135-144.

22. Kacerovsky M, Pliskova L, Bolehovska R, Skogstrand K, Hougaard DM, et al (2012) The impact of the microbial load of genital mycoplasmas and gestational age on the intensity of intraamniotic inflammation. Am J Obstet Gynecol 206: 342-348.

23. McClure EM, Dudley DJ, Reddy U, Goldenberg RL (2010) Infectious causes of stillbirth. Clin Obstet Gynecol 53: 635-645.

24. Leli C, Mencacci A, Latino MA, Clerici P, Rassu M, et al. (2017) Prevalence of cervical colonization by Ureaplasma parvum, Ureaplasma urealyticum, Mycoplasma hominis and Mycoplasma genitalium in childbearing age women by a commercially available multiplex real-time PCR: An Italian observational multicentre study. J Microbiol Immunol Infect 20: 1-6.

25. Choi SJ, Park SD, Jang IH, Uh Y, Lee A (2012) The prevalence of vaginal microorganisms in pregnant women with preterm labor and preterm birth. Ann Lab Med 32: 194-200.

26. Marovt M, Keše D, Kotar T, Kmet N, Miljković J, et al. (2015) Ureaplasma parvum and Ureaplasma urealyticum detected with the same frequency among women with and without symptoms of urogenital tract infection. Eur J Clin Microbiol Infect Dis 34: 1237-1245.

27. Capoccia R, Greub G, Baud D (2013) Ureaplasma urealyticum, Mycoplasma hominis and adverse pregnancy outcomes. Curr Opin Infect Dis 26: 231-240. 